\title{
Effect of Cooking Time on Physical Properties of Almond Milk-Based Lemak Cili Api Gravy
}

\author{
Nurathirah Saruan, Norazlin Abdullah*, Norhayati Muhammad and Balkis A. Talip \\ Department of Technology and Natural Resources, Faculty of Applied Sciences and Technology, \\ Universiti Tun Hussein Onn Malaysia, Pagoh Educational Hub, 84600 Pagoh, Johor, Malaysia.
}

Received 30 September 2017; accepted 30 April 2018; available online 1 August 2018

DOI: https://10.30880/jst.2018.10.02.017

\begin{abstract}
One of the crucial elements in developing or reformulating product is to maintain the quality throughout its entire shelf life. This study aims to determine the effect of different cooking time on the almond milk-based of lemak cili api gravy. Various cooking times of 5, 10, 15, 20, 25 and 30 minutes were employed to the almond milk-based lemak cili api gravy followed by determination of their effects on physical properties such as total soluble solids content, $\mathrm{pH}$ and colour. $\mathrm{pH}$ was determined by using a $\mathrm{pH}$ meter. Refractometer was used to evaluate the total soluble solids content of almond milk-based lemak cili api gravy. The colours were determined by using spectrophotometer which expressed as $L^{*}, a^{*}$ and $b^{*}$ values. Results showed that almond milk-based lemak cili api gravy has constant values of total soluble solids with $\mathrm{pH}$ range of 5 to 6 , which can be classified as low acid food. Colour analysis showed that the lightness $\left(L^{*}\right)$ and yellowness $\left(\mathrm{b}^{*}\right)$ are significantly increased while redness $\left(\mathrm{a}^{*}\right)$ decreased. In conclusion, this study shows that physical properties of almond milk-based lemak cili api gravy changes by increasing the cooking time.
\end{abstract}

Keyword: Colour; lemak cili api; gravy; paste; pH; total soluble solids.

\section{Introduction}

Lemak cili api is a hot and spicy delicacy that is popular in Negeri Sembilan [1]. It comprises of three main ingredients which are turmeric, coconut milk and bird's eye chillies [2]. Combination of other ingredients such as onions, lemongrass, and other spices makes a perfect blend of fresh concoction that is balanced with salt and sugar [3]. Although it may consist of different variation and styles due to different preference in food, most Malay traditional cuisine is believed to have same similarities in term of characteristics of the food which are strong, spicy and aromatic. Commonly, lemak cili api is prepared from onion, garlic, lemon grass, bird's eye chillies, ginger, and additive such as salt and sugar by blending them all together to obtain a homogenous green-yellow paste that provide colour, spicy taste and authentic fragrant dish. Physical and chemical properties changes in food components that are caused by temperature changes and closely related to the quality of food and acceptance of consumer. Thus, it turns into desired qualities as the product builds. Food quality on products is important for consumer requirements, defined in term of physical properties such as appearance and colour which influence the standard acceptance range and qualities for food to assure quality control and assurance of food. Variations of processing such as cooking, storage, and evaporation will influence the overall properties of the final product in terms of taste, colour, and texture [4]. The changes of colour, $\mathrm{pH}$ and total soluble solids of lemak cili api gravy after being cooked could be related with people in different ways due to the influences of scents and colours that create feeling to increase purchase probability that helps with consumer preference [5]. Owing this information, this study aims to investigate the effect of cooking time on the physical properties of almond milk-based lemak cili api gravy representing the quality of food and commercialising traditional food.

\section{Materials and Methods}

\section{Ingredients preparation}

Cane sugar (Gula Prai, MSM Malaysia Holding Berhad), salt (STC fine salt, STC SUPERB Sdn. Bnd) and Malabar tamarind (Asam Jawa Penguin, Kim Loong Huat 
Industries Sdn. Bhd) were purchased from a local supermarket (Wellward, in Batu Pahat, Malaysia). The remaining ingredients used like onion, garlic, turmeric, lemon grass, ginger, birds's eye chillies and almond were bought fresh to maintain the quality.

Almond milk used as substitute for coconut milk was extracted by blending the whole almond nuts with tap water. All fresh ingredients such as onion, garlic, ginger, turmeric, lemon grass and birds's eye chillies were sorted, peeled, trimmed, washed and weighed according to the recipe in Table 1 .

\section{Lemak cili api paste and gravy preparation}

Lemak cili api paste were prepared based on an original recipe [6] with some modification to reduce the fat source. The compositions of lemak cili api paste are given in Table 1. Fresh ingredients such as onion, garlic, lemon grass, and ginger were peeled and homogenised in order to make a $202 \mathrm{~g}$ of mixture using a knife mill (HR7628/00, Philips, Jakarta).

Lemak cili api gravy was cooked by using a controlled temperature crepe maker machine (JB35-2, Star Choice, Russia) and initial temperature were set at $70{ }^{\circ} \mathrm{C}$ for 5 minutes to simmer the paste then increase to $140{ }^{\circ} \mathrm{C}$ as the remaining ingredients which are almond milk, salt, sugar, tamarind, and water as well as lemak cili api paste were added. Physical properties of lemak cili api gravy were determined at a 5 minute interval for 30 minutes.

\section{Physical properties determination}

The $\mathrm{pH}$ value of $10 \mathrm{ml}$ of homogenised almond milk-based lemak cili api gravy was measured by using a $\mathrm{pH}$ meter (Eutech, PH700, USA), which was calibrated with standard buffers of $\mathrm{pH} 4.0, \mathrm{pH} 7.0, \mathrm{pH} 10.0$ before the measurement [7].

Total soluble solids (TSS) content of almond milk-based lemak cili api gravy was measured by using a refractometer (PALBX/RI, ATTAGO, Japan), which was calibrated by using distilled water. The surface of lens was washed with distilled water and dried with paper towel to remove excess water then tested with lemak cili api gravy [8].

The colours of cooked gravy of almond milk-based lemak cili api were determined by using spectrophotometer (MiniScanE2, Hunter lab, USA). Cleaned petri dish containing the almond milk-based lemak cili api gravy was placed below the light source and postprocessing $L, a$ and $b$ values were recorded [9]. The colour was expressed in CIE Lab system $L^{*}, a^{*}$, and $b^{*}$ values, where $L^{*}$ indicate lightness on a 0-100 scale from black to white, $a^{*}$ red $(+)$ and green $(-)$, and $b^{*}$ yellow (+) and blue (-).

The volume of almond milk-based lemak cili api gravy was measured by using measuring cylinder. Almond milk-based lemak cili api gravy were measured for initial value at a 5 minutes interval for 30 minutes.

Table 1 Formulation of almond milk-based lemak cili api paste using selected spices.

\begin{tabular}{|c|c|c|}
\hline No & Ingredient & Percentage (\%) \\
\hline 1 & Onion & 11.08 \\
\hline 2 & Garlic & 2.77 \\
\hline 3 & Turmeric & 0.55 \\
\hline 4 & Lemon grass & 2.22 \\
\hline 5 & Bird's eye chilies & 2.77 \\
\hline 6 & Malabar tamarind & 0.67 \\
\hline 7 & Salt & 1.11 \\
\hline 8 & Sugar & 0.11 \\
\hline 9 & Ginger & 1.11 \\
\hline 10 & Almond milk & 22.17 \\
\hline 11 & Water & 55.43 \\
\hline & Total & 100.00 \\
\hline
\end{tabular}

\section{Results and Discussion}

The changes in $\mathrm{pH}$ of almond milk-based lemak cili api gravy during 30 minutes cooking time are shown in Table 2. Initial value of samples at 5 minutes was 6.13 which decreased to 5.96 at the end of 30 minutes of cooking time. This could be the results of loss of chlorophyll of certain ingredients due to heating process that affect its stability [10]. In addition, the degradation of bioactive compounds in vegetables may occur during cooking process, causing change in physical characteristics and chemical composition [11]. The reduction of volume affected by evaporation process during cooking time may also contribute to the changes of the samples (Table 2). When comparing the $\mathrm{pH}$ value, it constantly decreases at 5, 10 and 25 minutes of cooking time, the content of $\mathrm{pH}$ value were significant $(p<0.05)$ at 5,25 and 30 minutes of cooking time. This shows that almond milkbased lemak cili api is classified as a low acid 
canned food due to its $\mathrm{pH}$ of 5-6 and water activity greater than 0.85 [12].

Table 2 also shows the changes in TSS content. Approximately $7.25-8.05 \%$ of TSS changes had showed at 5 to 30 minutes of cooking time. However, the changes of TSS were slightly increased at minute $10(7.25 \%)$ and $15(8.05 \%)$ during the process. This result showed similar finding by Khan (2007) which has studied on the heat treatment process of the orange fruit for 15 minutes at $50{ }^{\circ} \mathrm{C}$. The study had shown that the heat treatment slows down the ripening process and delaying soluble solid increment [13]. The same study had also determined that the amount of TSS gradually increased during storage for 60 days (8.66\%). TSS corresponds with temperature applied on food is based on a study by Kurca [14] on black carrot. The anthocyanin properties that are highly reactive causes increase in solid content during heating as reacting molecules become closer when the product is concentrated [15].
Colour evaluation on the almond milkbased lemak cili api gravy was done as the heat treatment with temperature more than 60 ${ }^{\circ} \mathrm{C}$ causes pigment destruction that is expressed in term of colour parameter $L^{*}, a^{*}$ and $b^{*}$ values [16]. $L^{*}$ value for gravy shows a high scale in lightness which ranging from 61.1855.41 for 30 minutes of cooking duration. Meanwhile, for $a^{*}$ (green) and $b^{*}$ (yellowness) values, it shows $a^{*}$ have higher negative value (green) (-6.06 until -4.42) as for $b^{*}$ value have higher positive value (yellowness) ranging from 37.44 to 42.32 , respectively. The main colorant affect in almond milk-based lemak cili api gravy was due to the incorporation of turmeric (curcumin) that gives yellow colour to the gravy as well as due to acid that neutralises the $\mathrm{pH}$ value range [17]. A study by Weeranakorn [18] on fortification of calcium on green curry as an alternative source of calcium on traditional food shows a change in $L^{*}$ value compared to control with higher $b^{*}$ value which gives it greenish-yellow colour.

Table 2 Physical properties of almond milk-based lemak cili api gravy over cooking time.

\begin{tabular}{|c|c|c|c|c|c|c|}
\hline \multirow{2}{*}{$\begin{array}{c}\text { Time } \\
(\mathrm{min})\end{array}$} & \multirow{2}{*}{$\mathrm{pH}$} & \multirow{2}{*}{ TSS $(\%)$} & \multicolumn{3}{|c|}{ Colour } & $\begin{array}{c}\text { Volume } \\
(\mathrm{ml})\end{array}$ \\
\cline { 4 - 7 } & & & $\mathrm{L}$ & $\mathrm{a}$ & $\mathrm{b}$ & 990 \\
\hline 5 & $6.13 \pm 0.007^{\mathrm{a}}$ & $7.25 \pm 0.071^{\mathrm{c}}$ & $61.18 \pm 0.28^{\mathrm{a}}$ & $-6.06 \pm 0.33^{\mathrm{c}}$ & $38.17 \pm 2.63^{\mathrm{ab}}$ & $990.06^{\mathrm{b}}$ \\
\hline 10 & $6.03 \pm 0.021^{\mathrm{bc}}$ & $7.25 \pm 0.071^{\mathrm{c}}$ & $57.19 \pm 0.55^{\mathrm{b}}$ & $-5.44 \pm 0.06^{\mathrm{b}}$ & $42.32 \pm 4.53^{\mathrm{a}}$ & 970 \\
\hline 15 & $6.07 \pm 0.049^{\mathrm{ab}}$ & $8.05 \pm 0.071^{\mathrm{ab}}$ & $55.69 \pm 1.08^{\mathrm{bc}}$ & $-4.55 \pm 0.21^{\mathrm{a}}$ & $38.42 \pm 0.07^{\mathrm{ab}}$ & 950 \\
\hline 20 & $6.04 \pm 0.021^{\mathrm{bc}}$ & $8.20 \pm 0.280^{\mathrm{a}}$ & $54.26 \pm 0.078^{\mathrm{c}}$ & $-4.59 \pm 0.13^{\mathrm{a}}$ & $35.29 \pm 1.53^{\mathrm{b}}$ & 890 \\
\hline 25 & $5.92 \pm 0.021^{\mathrm{d}}$ & $7.70 \pm 0.140^{\mathrm{b}}$ & $55.53 \pm 0.21^{\mathrm{bc}}$ & $-5.42 \pm 0.05^{\mathrm{b}}$ & $37.96 \pm 0.58^{\mathrm{ab}}$ & 840 \\
\hline 30 & $5.96 \pm 0.057^{\mathrm{cd}}$ & $7.85 \pm 0.210^{\mathrm{ab}}$ & $55.41 \pm 1.62^{\mathrm{bc}}$ & $-4.42 \pm 0.14^{\mathrm{a}}$ & $37.44 \pm 1.75^{\mathrm{ab}}$ & 820 \\
\hline
\end{tabular}

Different letters in same column means the value are significantly different $(p<0.05)$, the mean of a is higher than $b$ and $c(a>b>c)$.

\section{Conclusion}

Cooking time has significant effects on $\mathrm{pH}$, TSS and colour of almond milk-based lemak cili api gravy. TSS value increased slightly over cooking time. Heat may increase the $L^{*}$ value of lemak cili api gravy due to the degradation of colour of ingredients such as turmeric and bird's eye chilllies. This study leads to the investigation of factors that may affect the quality of food due to cooking process.

\section{Acknowledgements}

The authors would like to thank the Universiti Tun Hussein Onn Malaysia for research facilities and its financial support under Short Term Grant with project number U538.

\section{References}

[1] Brissenden, R. (2007). Southeast Asian Food: Classic and Modern Dishes from Indonesia, Malaysia, Singapore, Thailand, Laos, Cambodia, and Vietnam. Tuttle Publishing, USA.

[2] Betty. S (2005). Best of Malaysian Cooking. Marshall Cavendish Cuisine. Marshall International (Asia) Private Limited, Singapore

[3] Uhl. S.R. (2000). Hand Book of Spices, Seasonings, and Flavorings. Technomic publication company, Inc. USA. 
[4] Canela, M.A. Alvarez, E, and Maceiras. R. (2005). "Rheological Behaviour of Fresh and Frozen Food Creams". Eurotherm Seminar 77- Heat and Mass Transfer in Food Processing. June 2022, 2005.

[5] Kotler, P. (1973), "Atmospherics as a Marketing Tool" in Journal of Retailing, Vol. 49. No. 4 pp. 48 - 61.

[6] Karangkraf (2001), 50 Ayam. Kompilasi Majalah Karangkraf. Dasar Cetak (M) Sdn. Bhd. Selangor.

[7] Nummer, A. B. (2008). "Food Acidity and Safety". All Current Publications. Paper 1110. https://digitalcommons.usu. edu/ extension_curall/1110

[8] Aoun. A.B, (2013). "Evaluation of Fruit Quality Traits of Traditional Varieties of Tomato (Solanum Lycopersicum) Grown in Tunisia" in Scientific Researh Publishing, Vol. 7. No. 10 pp. 350-354.

[9] Inchuen. S., Pornchaloempong. P., Narkrugsa. W., \& Tungkananuruk. K. (2011). "Influence of Heat Treatment on Antioxidant Capacity and Color of Thai Red Curry Paste" in Natural Science, Vol. 45. pp. $136-146$.

[10] Ifesan, B.O.T. (2010). "Stability of Antibacterial Property of Thai Green Curry during Chilled Storage" in Journal of Food Processing and Preservation, Vol. 34. pp. 308-321.

[11] Azizah, A.H., Wee, K. C., Azizah, O. and Azizah, M. (2009). "Effect of Boiling and Stir Frying on Total Phenolics, Carotenoids and Radical Scavenging Activity of Pumpkin (Cucurbita Moschato)" in International Food Research Journal, Vol.16. pp 4551.

[12] USFDA. (2017). Acidified and LowAcid Canned Food: Thermally Processed Low-Acid Foods Packed in Hermetically Sealed Containers 21 CFR113, [cited: 2017] [Available from http://www.fda.

gov/ora/inspect_ref/igs/lacfpt1/

lacfpt 101.html].

[13] Khan, G.H (2007). "Effect of Heat and Cold Treatments on Post-Harvest Quality of Sweet Orange cv. Blood Red" in Sarhad Journal of Agriculture, Vol. 23. No.1 pp. 39-41.

[14] Kurca, A. (2007). "Effects of Temperature, Solid Content, and $\mathrm{pH}$ on the Stability of Black Carrot Anthocyanins". in Food Chemistry, Vol. 101. pp 212-218.

[15] Nielsen, S. (1993). Chemistry of Aseptically Processed Foods in Principles of Aseptic Processing and Packaging. Food Processors Institute, Washington, DC. pp. 87-111.

[16] Inchuen, S., Pornchaloempong, P., Narkrugsa, W., and Tungkananuruk, K. (2011). "Influence of Heat Treatment on Antioxidant Capacity and Color of Thai Red Curry Paste" in Natural Science, Vol.45. pp. $136-146$.

[17] Hirasa, K. (1998). Spice Science and Technology. Marcel Dekker, Inc., New York.

[18] Weeranakorn, M. (2015). "Fortification of Calcium in Thai Green Curry Paste" in Food and Applied Bioscience Journal. Vol. 3. No. 2 pp. 85-99. 